\title{
Development and Characterization of Superparamagnetic Nanomaterial to Determine Its Potential Application in Removing the Bitterness of Table Olives
}

\author{
Elif Savas, ${ }^{1 *}$ Oznur Karaagac, ${ }^{2}$ Hakan Kockar, ${ }^{3}$ \\ Mihrap Yaşar Kaya, ${ }^{3}$ Sümeyye Aydoğan Türkoğlu, ${ }^{3}$ and Feray Kockar $^{3}$ \\ ${ }^{1}$ Food Engineering Department, Engineering Faculty, Balikesir University, \\ 10145, Cagis, Balikesir, Turkey \\ ${ }^{2}$ Physics Department, Science \& Literature Faculty, Balikesir University, \\ 10145, Cagis, Balikesir, Turkey \\ ${ }^{3}$ Molecular Biology and Genetics Department, Science \& Literature Faculty, Balikesir University, \\ 10145, Cagis, Balikesir, Turkey
}

(Received October 28, 2019; accepted December 27, 2019)

Keywords: superparamagnetic nanomaterial, iron oxide nanoparticles, enzyme immobilization, $\beta$-glucosidase, debittering olives

The aim of this study is to develop stable superparamagnetic iron oxide nanoparticles (SPIONs) for the immobilization of $\beta$-glucosidase. The goal is to figure out the possibility of applying immobilization techniques in the debittering of olives. In the present study, SPIONs with a size of $\sim 9 \mathrm{~nm}$ were synthesized by co-precipitation, and immobilization was carried out by the formation of covalent bonds between $\beta$-glucosidase and SPIONs. The properties of the free enzymes immobilized with SPIONs were compared by using commercial $\beta$-glucosidase as a standard. The immobilized enzymes were characterized by using techniques including X-ray diffraction (XRD), Fourier transform infrared spectroscopy (FTIR), and transmission electron microscopy (TEM). The results showed that SPIONs are an effective and suitable material for the immobilization of $\beta$-glucosidase as well as a potential nanomaterial for the elimination of olive bitterness originating from oleuropein.

\section{Introduction}

Various studies on immobilized enzymes and their matrices (support phases) have been reported. Polymers, ${ }^{(1-3)}$ zirconia $^{(4)}{ }^{\text {zeolite, }}{ }^{(5)}$ chitosan, ${ }^{(6)}$ and carbon nanoparticles ${ }^{(7)}$ are some matrix materials that provide support to the binding of a particular enzyme. The immobilization principle is to remove the enzyme from the reaction mixture without any damage to its function and structure. Thus, immobilization technology allows the reuse of the enzyme eliminated from the reaction mixture. Moreover, enzyme stability is enhanced with this technology. ${ }^{(8)}$ Enzyme applications have also changed with the development of technology over time and the 
changing needs/demands connected with enzyme applications. In immobilization technology, iron oxide nanoparticles (IONs) are an alternative matrix material. ${ }^{(9-12)}$ Most of the properties of IONs satisfy biotechnological requirements, such as small particle size, high surface area, superparamagnetic character, low toxicity, and biocompability. ${ }^{(13,14)}$ Many methods for the immobilization of both water-soluble and membrane enzymes have been reported, and some differences have been found in the activities of the immobilized and natural forms of the enzymes. $\mathrm{We}^{(10)}$ showed that the immobilized enzymes can be captured in a local area in a tube and navigated away by a $\mathrm{NdFeB}$ magnet. IONs have superior controllability in the immobilization process with easy separation of the enzyme by using an external magnetic field. ${ }^{(9,10)}$ The adsorption on the matrix occurs in different ways, such as binding with covalent bonds, ${ }^{(7,10)}$ adsorption on a substance present on the matrix, ${ }^{(4)}$ entrapment in a gel, and encapsulation. ${ }^{(2)}$ Another absorption reaction involves bonds formed by carbodiimide activation, which has particular interest because the method based on this reaction is simple and highly effective. ${ }^{(15,16)}$

$\beta$-glucosidase, which plays an active role in regulating the systemic physiological activities of plants, is also reported to be responsible for the food quality and flavor. The $\beta$-glucosidases in olives catalyze the hydrolysis of phenolic glucosides such as oleuropein, demethyloleuropein, verbascoside, and luteolin-7-glucoside found in olives, which have an adverse or positive impact on health. ${ }^{(17)}$ Moreover, they are effective for removing the bitterness of olive fruit during table olive production. The debittering process makes olives edible and palatable.

In previous studies, various support materials (matrices) have been used for the adsorption of the enzyme. Many methods have been applied to carry out the binding reaction through the formation of covalent bonds between the enzyme and the matrix. ${ }^{(18-25)}$ The type of reaction and its mechanism vary from enzyme to enzyme. Thus, the most important part of the immobilization process is the development of the support matrix. There has been no study on immobilizing the olive $\beta$-glucosidase on superparamagnetic iron oxide nanoparticles (SPIONs) by carbodiimide activation, although various studies about immobilization have been reported. ${ }^{(6,8,17-19)}$

Therefore, in the present study, the $\beta$-glucosidase found in olive fruit was immobilized using SPIONs. For this purpose, the $\beta$-glucosidase extracted from olives was selected as the main compound to be immobilized. Commercial $\beta$-glucosidase was also obtained for comparison with the extracted/isolated enzyme in terms of immobilization performance. The immobilization of $\beta$-glucosidase by covering with SPIONs was investigated by Fourier transform infrared spectroscopy (FTIR). The results of magnetic measurement showed that the olive $\beta$-glucosidase immobilized using SPIONs exhibit the superparamagnetic property similarly to a commercial $\beta$-glucosidase. It was also determined that SPIONs are an effective and suitable matrix for the immobilization of $\beta$-glucosidase. In this study, we investigated the possibility of $\beta$-glucosidase usage in table olive processing by the immobilization of the enzyme using SPIONs without any denaturation. The characterization of the immobilization process with the SPIONs was carried out to determine their potential for reuse. 


\section{Materials and Methods}

\subsection{Materials}

Commercial $\beta$-glucosidase (Rapidase ${ }^{\mathrm{TM}}$ ) was obtained from DNS Food Ingredients, Denmark. The protein marker used was obtained from Fermentas (Waltham, Massachusetts, ABD) and olive fruits (Olea europaea L.) including "Edremit cultivar" were obtained from Edremit/Balikesir in Turkey.

\subsection{Synthesis of IONs}

The IONs were obtained by co-precipitation in air at room temperature. Iron (II) chloride tetrahydrate (Merck, $\geq 99 \%$, analytical grade), iron (III) chloride hexahydrate (Sigma-Aldrich, $\geq 99 \%$, analytical grade), and ammonium hydroxide (Merck, 25\% ammonium in water) were used for the synthesis. $28.38 \mathrm{~g}$ ferric and $13.92 \mathrm{~g}$ ferrous salts were dissolved in $50 \mathrm{ml}$ deionized water and a base solution was added to the salt solution under mechanical stirring. The solution was allowed to remain at room temperature for 20 min since the reaction was carried out during this period. After the reaction, the precipitate was washed three times with deionized water and dried in an oven overnight to remove free water. ${ }^{(26)}$

\subsection{Extraction and purification of $\beta$-glucosidase from olive fruits}

The seed was removed from each fruit and the cored fruit was sliced for the maceration process. For this purpose, the sliced olives were titrated with $20 \mathrm{vol}$ of acetone at $-20{ }^{\circ} \mathrm{C}$. The maceration solution was left to stand at $-20{ }^{\circ} \mathrm{C}$ for $15 \mathrm{~min}$ and the supernatant was removed by decantation. The precipitate was treated with $8 \mathrm{vol}$ of acetone $(200 \mathrm{ml})$. This procedure was repeated until a supernatant without any color was obtained. To obtain the crude extract, $0.25 \mathrm{~g}$ of the protein precipitate was extracted with $17.5 \mathrm{ml}$ of $0.1 \mathrm{M}$ borate buffer $(\mathrm{pH}$ 9) containing $5 \mathrm{mM}$ EDTA, $0.25 \%$ DTT $(\mathrm{w} / \mathrm{v})$, and $1 \mathrm{mM}$ PMSF. Olive $\beta$-glucosidase was purified by two sequential steps as described in Kara et al. ${ }^{(17)}$ Specifically, after gentle stirring for $3 \mathrm{~h}$ at room temperature, the coupled red sepharose derivative was washed with $1 \mathrm{~L}$ of water and then $200 \mathrm{~mL}$ of $0.05 \mathrm{M}$ Tris ( $\mathrm{pH} 7.5){ }^{(27)}$ The enzyme solution $(3 \mathrm{ml})$ was loaded into the column $[1.0 \mathrm{~cm}$ diameter $\times 5.0 \mathrm{~cm}$ length, balanced with $50 \mathrm{mM}$ sodium phosphate buffer $(\mathrm{pH} 6.8)$ containing $\left.1 \mathrm{M}\left(\mathrm{NH}_{4}\right)_{2} \mathrm{SO}_{4}\right]$. The crude enzyme was eluted by using 1.0-0.0 M $\left(\mathrm{NH}_{4}\right)_{2} \mathrm{SO}_{4}$ with a linear gradient in the same buffer. The proteins containing the highest $\beta$-glucosidase activity were selected and used as the purified enzyme for the next step after confirming its homogeneity by gel electrophoresis.

\subsection{Determination of $\beta$-glucosidase activity and its protein content}

The enzyme activity of the immobilized and natural $\beta$-glucosidases was measured using para-nitrophenyl- $\beta$-d-glucopyranoside (p-NPG) as a substrate. ${ }^{(17)}$ The reaction mixture 
contained $0.05 \mathrm{M}$ sodium acetate buffer $(2.9 \mathrm{ml})$ at $\mathrm{pH} 5.5,5 \mathrm{mM}$-NPG $(0.07 \mathrm{ml})$, and enzyme solution $(0.07 \mathrm{ml})$. The mixture was incubated at $37{ }^{\circ} \mathrm{C}$ for $30 \mathrm{~min}$ and the reaction was blocked by adding $0.5 \mathrm{M}$ sodium carbonate $(0.07 \mathrm{ml})$. After the reaction, 4-nitrophenol was released into the medium. The yield of released 4-nitrophenol was measured using a UV-Vis spectrophotometer (Thermo) at $410 \mathrm{~nm}$. The concentration of released 4-nitrophenol was determined according to the standard p-nitrophenol. Enzyme activity was determined as the amount of p-nitrophenol in $\mu \mathrm{mol}$ formed per minute in the reaction mixture. The protein was quantified by the Bradford method using bovine serum albumin as a standard. All enzyme assays were performed in triplicate and reported as mean $\pm \mathrm{SD}$.

\subsection{Immobilization of olive $\beta$-glucosidase}

Purified olive $\beta$-glucosidase was used as the main substrate for immobilization. In addition, the recombinant $\beta$-glucosidase derived from fungi (Rapidase ${ }^{\mathrm{TM}}$ ) was also exposed to the same applications for comparison with the purified enzyme. 20-100 $\mathrm{mg}$ of IONs was placed in $2 \mathrm{ml}$ buffer $\mathrm{A}(0.003 \mathrm{M}$ phosphate, $\mathrm{pH} 6,0.1 \mathrm{M} \mathrm{NaCl})$ to immobilize $\beta$-glucosidase on the IONs. After $0.5 \mathrm{ml}$ of carbodiimide solution $(0.025 \mathrm{~g} / \mathrm{mL})$ was placed in the reaction medium, sonication was performed for $10 \mathrm{~min}$. $2 \mathrm{ml}$ of purified $\beta$-glucosidase was added to the medium, and then the solution was sonicated for another $30 \mathrm{~min}$. The same procedure was carried out for commercial $\beta$-glucosidase $(\mathrm{C} \beta)(78 \mu \mathrm{g})$ with $75 \mathrm{mg}$ of IONs.

\subsection{Protein immobilization yield}

The immobilization efficiency was evaluated in terms of protein yield by measuring the difference between the protein concentrations in the $\beta$-glucosidase solution observed before and after the immobilization process according to the following equation:

$$
\text { Protein immobilization yield }(\%)=\frac{C i-C f}{C i} \times 100 \text {. }
$$

In the formulization, $C i$ is the initial protein concentration in the $\beta$-glucosidase solution and $C f$ is the final protein concentration in the solution after immobilization.

\subsection{Characterization techniques}

The crystal structure of the IONs was characterized by a Philips Analytical X-ray diffractometer using $\mathrm{CuK}_{\alpha}$ radiation $(\lambda=1.54056 \AA)$ in the range of $20^{\circ}<2 \theta<80^{\circ}$. Images of the nanoparticles were taken by a Tecnai G2 F30 high-resolution transmission electron microscopy (TEM) system operating at an accelerating voltage of $200 \mathrm{kV}$. The size of the nanoparticles $\left(d_{T E M}\right)$ was measured from the image using the ImageJ program. FTIR (PerkinElmer-1600 Series) was also employed to investigate the structure of the IONs, olive $\beta$-glucosidase-immobilized IONs ( $\beta$-IONs), and commercial- $\beta$-glucosidase immobilized IONs 
(C $\beta$-IONs). The magnetic properties of the IONs, $\beta$-IONs, and $\mathrm{C} \beta$-IONs were measured by a vibrating sample magnetometer (VSM, ADE EV9 Model) in the field range $\pm 20 \mathrm{kOe}$ (1 Oe intervals) at room temperature.

\section{Results and Discussion}

\subsection{Characterization of SPIONs}

The X-ray diffraction (XRD) pattern of the SPIONs is shown in Fig. 1. TEM images of the SPIONs were taken to determine their morphology and size. A TEM image is shown in Fig. 2. The particles show a moderate size distribution. The physical particle size $d_{T E M}$ is found to be $8.2 \pm 3.0 \mathrm{~nm}$, which is in good agreement with $d_{X R D}(8.7 \mathrm{~nm})$.

The IONs have a cubic spinel structure with the characteristic (311), (400), (422), (511), (440), and (622) peaks of iron oxide at around $2 \theta \approx 35,43,53,57,63$, and $74^{\circ}$, respectively, according to JCPDS card nos. 019-0629 and 039-1346. The mean particle size of the IONs, $d_{X R D}$, was calculated from the most intense peak (311) using the Scherrer equation ${ }^{(28)}$ and found to be $8.7 \mathrm{~nm}$. The FTIR analysis also confirmed the formation of the IONs.

\subsection{Olive $\beta$-glucosidase purification and immobilization onto SPIONs}

The olive $\beta$-glucosidase was purified by salting out with ammonium sulfate and using specifically designed sepharose-4B-L-tyrosine-l-napthylamine hydrophobic interaction chromatography. The purified protein migrated as a single polypeptide under $10 \%$ SDS-PAGE (sodium dodecyl sulfate gel electrophoresis). The molecular weight estimated by SDS-PAGE was $66 \mathrm{kDa}$. When the initial free $\beta$-glucosidase activity in the solution was $1644.87 \mathrm{U} / \mathrm{ml}$, the SPIONs immobilized $\beta$-glucosidase with an activity of $1669 \mathrm{U} / \mathrm{ml}$. The immobilized enzyme retained a similar activity balance.

The effects of several key immobilization conditions on the immobilization yield and enzyme activity were investigated. The activity of the immobilized $\beta$-glucosidase was

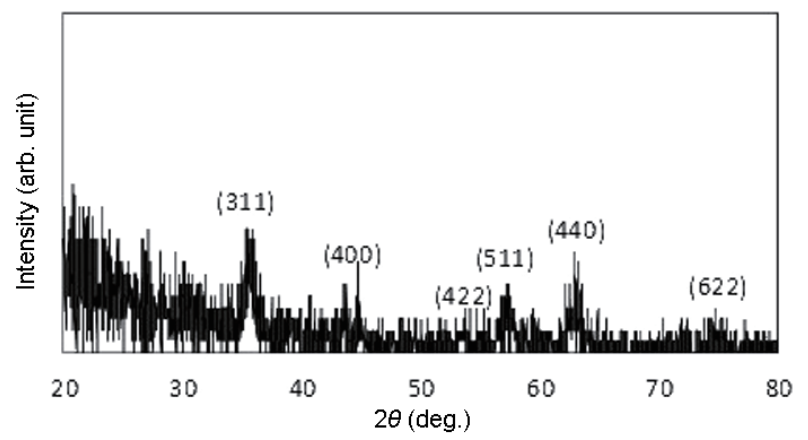

Fig. 1. XRD pattern of the SPIONs.

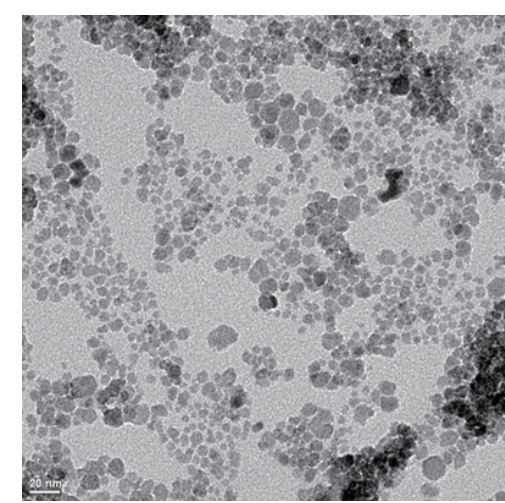

Fig. 2. TEM image of the SPIONs. 
determined using $\mathrm{p}-\mathrm{NPG}$ as a substrate. The $\beta$-glucosidase activity in the supernatant after immobilization was also determined. A rapid increase in the yield of immobilization from 30.7 to $100 \%$ as well as in the enzyme activity from 2820.51 to $4662.3931 \mathrm{U} / \mathrm{ml}$ was observed with increasing ION concentration from 5 to $25 \mathrm{mg}$ (Tables 1 and 2).

In general, the amount of enzyme immobilized on carriers strongly affects the performance of the immobilized enzyme. The exponential increase in enzymatic activity with the immobilization yield observed in the present study was found to be similar to that observed in a previous study. ${ }^{(25)}$ From the results, it was initially thought that there was an increase in the number of amide groups available for binding to the amine groups in the enzyme with a covalent bond. However, it was observed that a further increase in ION concentration to $100 \mathrm{mg}$ induced a decrease in enzyme activity. As a consequence, the results showed that the activity of the immobilized $\beta$-glucosidase did not increase, and that the number of amine groups in the support decreased. This limitation of the binding capacity of the enzyme is similar to that in a previous report. ${ }^{(29)}$ Accordingly, the maximum weight ratio of IONs to $\beta$-glucosidase was determined as 1/1091. Consequently, the most economically viable ratio of the ION to $\beta$-glucosidase concentrations during the immobilization process was about $1 / 1091$. In this ratio, $\beta$-glucosidase was completely bound to IONs. The binding between $\beta$-glucosidase and the nanoparticles (IONs) was of the monomolecular level in this study. This study provides a comparison of some properties of the immobilized and free enzymes. The operational stability of derivatives was studied and the enzyme remained active for a few cycles, which reinforces the importance of the use of these immobilized catalysts.

\subsection{Characterization of $\beta$-glucosidase-immobilized IONs}

FTIR analysis was performed in the $400-4000 \mathrm{~cm}^{-1}$ region, and the spectra of free $\beta$-glycosidase, the IONs, and the immobilized samples are given in Fig. 3. In Fig. 3(a), the

Table 1

Immobilization efficiencies of various SPION concentrations on olive $\beta$-glucosidase.

\begin{tabular}{cccccc}
\hline $\begin{array}{c}\text { SPIONs } \\
(\mathrm{mg})\end{array}$ & $\begin{array}{c}\text { Initial protein } \\
(\mu \mathrm{g})\end{array}$ & $\begin{array}{c}\text { Bound protein } \\
(\mu \mathrm{g})\end{array}$ & $\begin{array}{c}\text { Immobilization } \\
\text { efficiency }(\%)\end{array}$ & $\begin{array}{c}\text { Activity } \\
(\mathrm{EU} / \mathrm{mL})\end{array}$ & $\begin{array}{c}\text { Relative activity } \\
(\mathrm{EU} / \mathrm{mL})\end{array}$ \\
\hline 5 & 22.9 & 6.9 & 30 & 2821 & 60.5 \\
15 & 22.9 & 13.9 & 61 & 3898 & 83.6 \\
25 & 22.9 & 22.9 & 100 & 4662 & 100.0 \\
75 & 22.9 & 22.9 & 100 & 4140 & 88.8 \\
100 & 22.9 & 22.9 & 100 & 3207 & 68.8 \\
\hline
\end{tabular}

Table 2

Immobilization efficiencies of various SPION concentrations on commercial $\beta$-glucosidase.

\begin{tabular}{rccccc}
\hline $\begin{array}{c}\text { SPIONs } \\
(\mathrm{mg})\end{array}$ & $\begin{array}{c}\text { Initial protein } \\
(\mu \mathrm{g})\end{array}$ & $\begin{array}{c}\text { Bound protein } \\
(\mu \mathrm{g})\end{array}$ & $\begin{array}{c}\text { Immobilization } \\
\text { efficiency }(\%)\end{array}$ & $\begin{array}{c}\text { Activity } \\
(\mathrm{EU} / \mathrm{mL})\end{array}$ & $\begin{array}{c}\text { Relative activity } \\
(\mathrm{EU} / \mathrm{mL})\end{array}$ \\
\hline 5 & 78 & 14.5 & 18.5 & 15064 & 63.2 \\
15 & 78 & 41.1 & 52.6 & 21975 & 92.1 \\
25 & 78 & 54.1 & 69.4 & 22308 & 93.5 \\
75 & 78 & 75.8 & 97.4 & 23850 & 100.0 \\
100 & 78 & 78.0 & 100.0 & 23590 & 98.9 \\
\hline
\end{tabular}




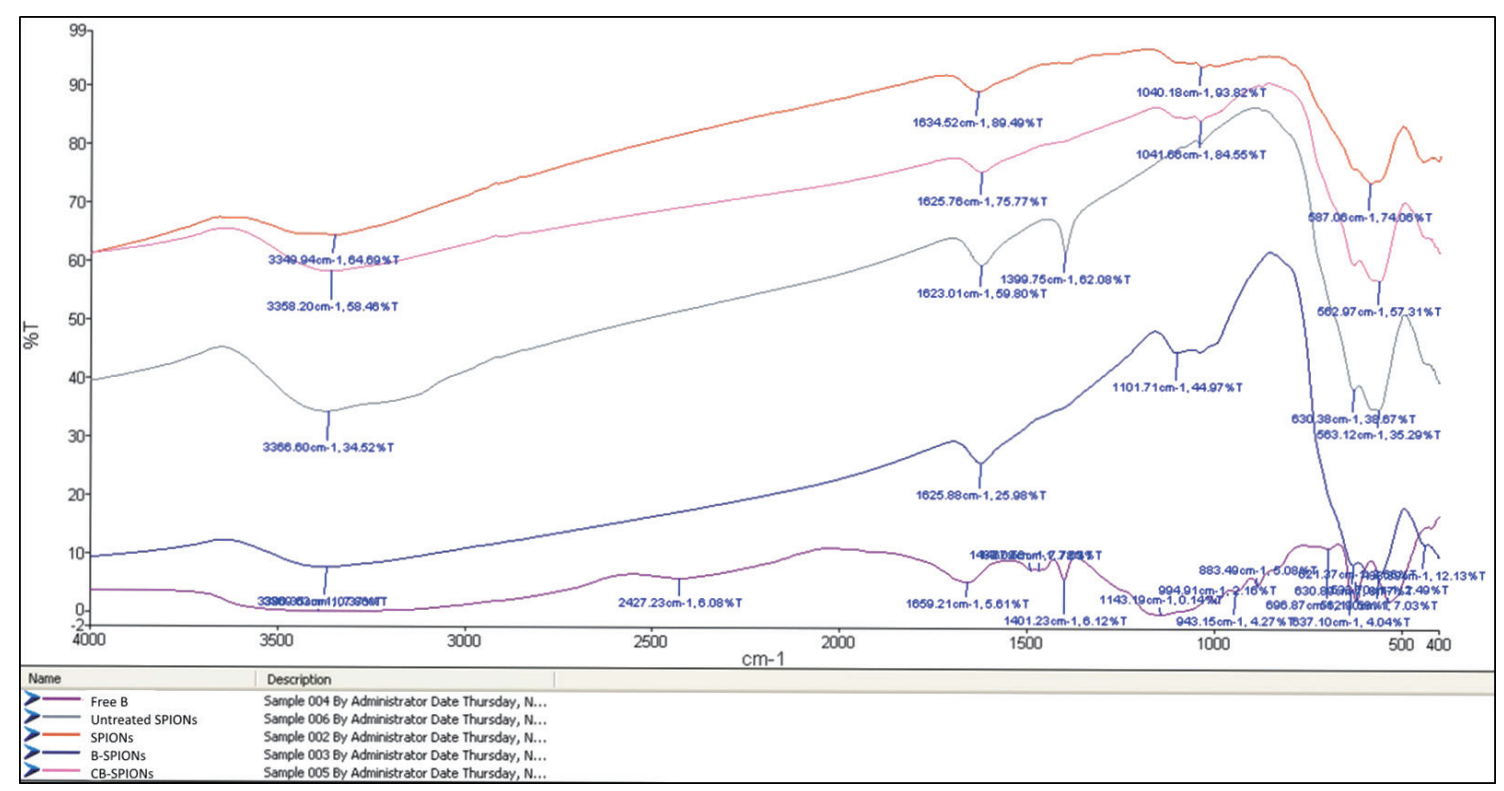

Fig. 3. (Color online) FTIR spectra of (a) free $\beta$-glucosidase, (b) SPIONs, (c) $\beta$-SPIONs, and (d) C $\beta$-SPIONs (* may represent the amine vibration band and + may represent the amide vibration band in the samples).

transmittance peaks of free $\beta$-glucosidase were observed. In the spectrum of the IONs in Fig. 3(b), the transmittance peaks of iron oxide were observed at about $580 \mathrm{~cm}^{-1}$, confirming $\mathrm{Fe}-\mathrm{O}$ bond vibration. ${ }^{(30)}$ In addition, the shoulder peak observed at around $625 \mathrm{~cm}^{-1}$ indicates $\gamma-\mathrm{Fe}_{2} \mathrm{O}_{3}$ formation $^{(31)}$ and also confirms ION formation. Peaks attributed to iron oxide (580 and $625 \mathrm{~cm}^{-1}$ ) were also observed in the spectra of $\beta$-IONs and C $\beta$-IONs in Figs. 3(c) and 3(d), respectively. A band was observed between 990 and $1100 \mathrm{~cm}^{-1}$; this band also appears in the spectra of $\beta$-IONs and C $\beta$-IONs. The peak at $1400 \mathrm{~cm}^{-1}$ in the spectra of free $\beta$-glucosidase and SPIONs, and the 545 and $620 \mathrm{~cm}^{-1}$ peaks of free $\beta$-glucosidase were absent in the spectra of $\beta$-IONs and C $\beta$-IONs. The spectra of free $\beta$-glucosidase, SPIONs, and $\beta$-IONs (or C $\beta$-IONs) indicate that SPIONs and $\beta$-glucosidase exist together in the sample. The FTIR measurements of the samples confirmed the presence of iron oxide and that immobilization occurred.

The FTIR spectra of free $\beta$-glucosidase, IONs, and $\beta$-IONs (or C $\beta$-IONs) indicate that IONs and $\beta$-glucosidase exist together in the sample. The FTIR measurements of the samples confirmed the presence of iron oxide and that immobilization occurred.

The magnetization curve revealed that the IONs are superparamagnetic with zero coercivity, $H_{c}$. The mean magnetic particle size $d_{M A G}$ (with standard deviation, $\sigma$ ) was calculated using relationships in Ref. 32 and found to be $7.5 \pm 0.4 \mathrm{~nm}$. This value is consistent with the $d_{X R D}$ and $d_{T E M}$ values. It was found that $\beta$-SPIONs and $\mathrm{C} \beta$-SPIONs retained their superparamagnetic character after the immobilization, and their $M_{S}$ values were 63.02 and $62.33 \mathrm{emu} / \mathrm{g}$, respectively. A small decrease ( $\sim 5 \%)$ in $M_{S}$ of SPIONs was observed after the immobilization for both $\beta$-SPIONs and C $\beta$-SPIONs. This was attributed to the binding of $\beta$-glucosidase to SPIONs, which leads to a reduction in the number of magnetic moments per weight in the volume fraction. The $M_{s}$ values of bare $\mathrm{Fe}_{3} \mathrm{O}_{4}$ nanoparticles and enzyme-immobilized 
phosphonomethyl iminodiacetic acid (PMIDA)-conjugated $\mathrm{Fe}_{3} \mathrm{O}_{4}$ nanoparticles are 65.4 and $48.3 \mathrm{emu} / \mathrm{g}$, respectively. A large decrease in $M_{S}(\sim 26 \%)$ was observed upon immobilization as compared with our results. This notable decrease was caused by the conjugation of PMIDA to the magnetite nanoparticles before urease immobilization through the carbodiimide reaction. Another study, ${ }^{(16)}$ in which carbodiimide activation was used to immobilize paraoxonase 1 to magnetite nanoparticles, obtained an $M_{S}$ reduction of $10 \%$ (from 54.81 to $49.25 \mathrm{emu} / \mathrm{g}$ ).

The magnetization curves of SPIONs, $\beta$-SPIONs, and C $\beta$-SPIONs measured at $\pm 20 \mathrm{kOe}$ are shown in Fig. 4, and magnifications of the curves are drawn at \pm 200 Oe. The saturation magnetization $M_{S}$ of SPIONs is $66.5 \mathrm{emu} / \mathrm{g}$ and the saturation field $H_{S}$ is 7713 Oe.

Magnetic measurements were also performed simultaneously with activity measurements until the activity of $\beta$-SPIONs ended. C $\beta$-SPIONs were also measured during the same period. The $M_{s}$ values of $\beta$-SPIONs and C $\beta$-SPIONs versus time (weeks) are given with the corresponding enzyme activities in Figs. 5(a) and 5(b), respectively. It was observed from Fig. 5 (a) that the $\beta$-SPIONs lost all their enzymatic activity after six weeks, whereas their $M_{S}$ values remained almost constant, confirming that olive $\beta$-glucosidase stay bounded to SPIONs. The $M_{S}$ value and activity of C $\beta$-SPIONs also remained almost constant during the six-week period [Fig. $5(\mathrm{~b})]$.

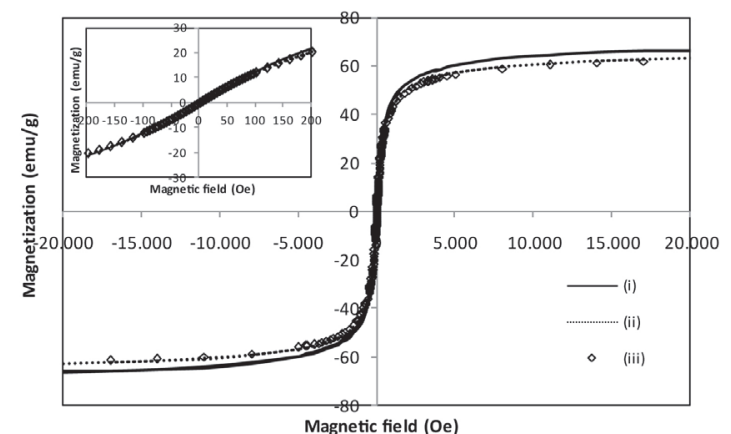

(a)

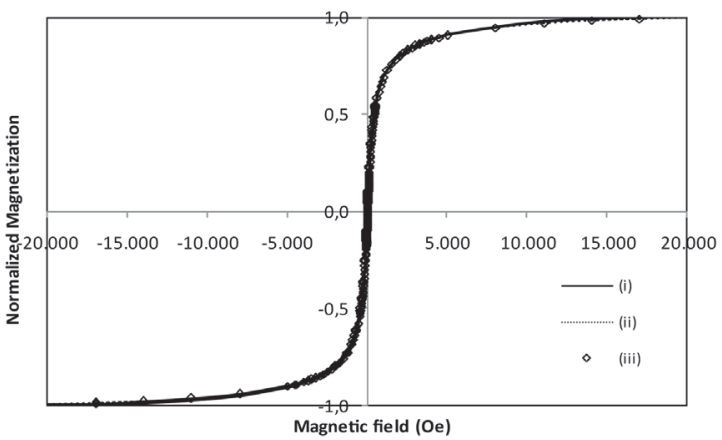

(b)

Fig. 4. (a) Magnetization vs magnetic field and (b) normalized magnetization curves of (i) SPIONs, (ii) $\beta$-ISPIONs, and (iii) C $\beta$-SPIONs [the inset in (a) shows the magnetization curves at $\pm 200 \mathrm{Oe}$ ].

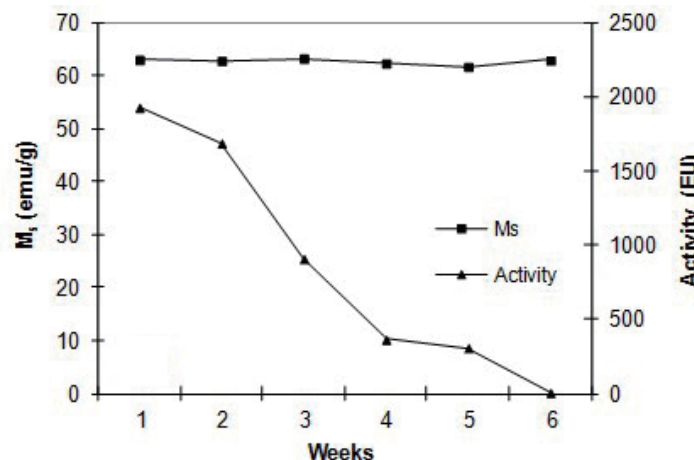

(a)

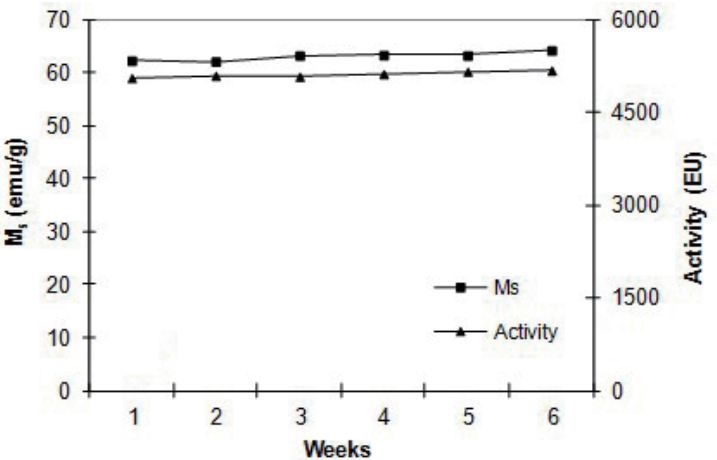

(b)

Fig. 5. Saturation magnetization values and enzyme activities of (a) $\beta$-SPIONs and (b) C $\beta$-SPIONs vs time (weeks). 


\section{Conclusion}

Olive and commercial $\beta$-glucosidases were successfully immobilized on SPIONs by carbodiimide activation. The SPIONs were synthesized by co-precipitation, and the XRD, FTIR, and TEM techniques were used for their characterization. The particle size was found to be $8.2 \pm 3.0 \mathrm{~nm}$ according to the obtained TEM image. Magnetic measurements made at room temperature showed that the nanoparticles were superparamagnetic and that their saturation magnetization was $66.5 \mathrm{emu} / \mathrm{g}$. FTIR verified the immobilization of the enzyme to the nanoparticles. It was observed that both samples (olive and commercial $\beta$-glucosidases) showed superparamagnetic behaviour after immobilization and retained their saturation magnetization during a six-week period. It can be concluded that it is convenient to immobilize $\beta$-glucosidase on SPIONs.

\section{Acknowledgments}

This study was supported by Turkish Research Council Project Grant No. 1100778 and Scientific Research Projects Unit of Balıkesir University Grant No. BAP.2014.0002.

\section{Data Availability}

The raw/processed data required to reproduce these findings cannot be shared at this time as they also form part of an ongoing study.

\section{References}

1 E. P. Cipolatti, A. Valério, G. Nicoletti, E. Theilacker, P. H. H. Araújo, C. Sayer, J. L. Ninow, and D. de Oliveira: J. Mol. Catal. B: Enzym. 109 (2014) 116. https://doi.org/10.1016/j.molcatb

2 X. Zhu, Y. Ma, C. Zhao, Z. Lin, L. Zhang, R. Chen, and W. Yang: Langmuir 30 (2014) 15229. https://doi. org/10.1021/la5035273

3 Y. R. Lee, B. Tang, H. Zhang, W. Bi, and K. H. Row: J. Liq. Chromatogr. Relat. Technol. 38 (2014) 613. https:// doi.org/10.1080/10826076.2014.936607

4 L. T. I. Živković, L. S. Živković, B. M. Babić, M. J. Kokunešoski, B. M. Jokić, and I. M. Karadžić: Biochem. Eng. J. 93 (2015) 73. https://doi.org/10.1016/j.bej.2014.09.012

5 O. Celikbicak, G. Bayramoglu, M. Y1lmaz, G. Ersoy, N. Bicak, B. Salih, and M. Y. Arica: Micropor. Mesopor. Mater. 199 (2014) 57. https://doi.org/10.1016/j.micromeso.2014.08.003

6 H. Mallin, M. Höhne, and U. T. Bornscheuer: J. Biotechnol. 191 (2014) 32. https://doi.org/10.1016/ j.jbiotec.2014.05.015

7 R. Pang, M. Li, and C. Zhang: Talanta 131 (2015) 38. https://doi.org/10.1016/j.talanta

8 J. C. Wu, C. H. Hutchings, M. J. Lindsay, C. J. Werner, and B. C. Bundy: J. Biotechnol. 193 (2014) 83. https:// doi.org/10.1016 / j.jbiotec.2014.10.039

9 S. Kumar, A. K. Jana, I. Dhamija, Y. Singla, and M. Maiti: Eur. J. Pharm. Biopharm. 85 (2013) 413. https:// doi.org/10.1016/j.ejpb.2013.06.019

10 Y. H. Ma, S. Y. Wu, T. Wu, Y. J. Chang, M. Y. Hua, and J. P. Chen: Biomaterials 30 (2009) 3343. https://doi. org/10.1016/j.biomaterials.2009.02.034

11 N. Sohrabi, N. Rasouli, and M. Torkzadeh: Chem. Eng. J. 240 (2014) 426. https://doi.org/10.1016/j.cej.2013.11.059

12 C. C. Yu, Y. Y. Kuo, C. F. Liang, W. T. Chien, H. T. Wu, T. C. Chang, F. D. Jan, and C. C. Lin: Bioconjug. Chem. 23 (2012) 714. http://dx.doi.org/10.1021/bc200396r

13 A. R. Simioni, F. L. Primo, M. M. A. Rodrigues, Z. G. M. Lacava, P. C. Morais, and A. C. Tedesco: IEEE Trans. Magn. 43 (2007) 2459. https://doi.org/10.1166/jnn.2006.511 
14 A. Tomitaka, A. Hirukawa, T. Yamada, S. Morishita, and Y. Takemura: J. Magn. Magn. Mater. 321 (2009) 1482. https://doi.org/10.1016/j.jmmm.2009.02.058

15 Y. Y. Chen, M. G. Tsai, M. C. Chi, T. F. Wang, and L. L. Lin: Int. J. Mol. Sci. 14 (2013) 4613. https://doi. org/10.3390/ijms14034613

16 F. Kockar, S. Beyaz, S. Sinan, H. Kockar, D. Demir, S. Eryilmaz, T. Tanrisever, and O. Arslan: J. Nanosci. Nanotechnol. 10 (2010) 7554. https://doi.org/10.1166/jnn.2010.2828

17 H. E. Kara, S. Sinan, and Y. Turan: J. Chromatogr. B 879 (2011) 1507. https://doi.org/10.1016/ j.jchromb.2011.03.036

18 J. Alftrén and T. J. Hobley: Appl. Biotechnol. Biochem. 169 (2013) 2076. https://doi.org/10.1007/s12010-013$0122-5$

19 T. Chen, W. Yang, Y. Guo, R. Yuan, L. Xu, and Y. Yan: Enzyme Microb. Technol. 63 (2014) 50-57. https://doi. org/10.1016/j.enzmictec.2014.05.008

20 H. K. Karagulyan, V. K. Gasparyan, and S. R. Decker: Appl. Biotechnol. Biochem. 146 (2008) 39. https://doi. org/10.1007/s12010-007-8065-3

21 G. Matthijs and E. Schacht: Enzyme Microb. Technol. 19 (1996) 601. https://doi.org/10.1016/S01410229(96)00067-1

22 R. Reshmi and S. Sugunan: J. Mol. Catal. B: Enzym. 85-86 (2013) 111. https://doi.org/10.1016/ j.molcatb.2012.08.007

23 M. Tu, X. Zhang, A. Kurabi, N. Gilkes, W. Mabee, and J. Saddler: Biotechnol. Lett. 28 (2006) 151. https://doi. org/10.1007/s10529-005-5328-3

24 M. L. Verma, C. J. Barrow, J. F. Kennedy, and M. Puri: Int. J. Biol. Macromol. 50 (2012) 432. https://doi. org/10.1016/j.ijbiomac.2011.12.029

25 J. Zhang, D. Wang, J. Pan, J. Wang, H. Zhao, Q. Li, and X. Zhou: J. Mol. Catal. B: Enzym. 104 (2014) 29. https://doi.org/10.1039/C4TB01439A

26 O. Karaagac, H. Kockar, S. Beyaz, and T. Tanrisever: IEEE Trans. Magn. 46 (2010) 3978. https://doi. org/10.1109/TMAG.2010.2076824

27 S. Sinan, F. Kockar, and O. Arslan: Biochimie 88 (2006) 565. https://doi.org/10.1016/j.biochi.2005.12.004

28 B. D. Cullity: Phys. Today. 10 (1957) 50. https://doi.org/10.1063/1.3060306

29 Y. Li, X. Y. Wang, R. Z. Zhang, X. Y. Zhang, W. Liu, X. M. Xu, and Y. W. Zhang: J. Nanosci. Nanotechnol. 14 (2014) 2931. https://doi.org/10.1166/jnn.2014.8625

30 S. A. Kahani and M. Jafari: J. Magn. Magn. Mater. 321 (2009) 1951. https://doi.org/10.1016/j.jmmm.2008.12.026

31 H. Namduri and S. Nasrazadani: Corros. Sci. 50 (2008) 2493. https://doi.org/10.1016/j.corsci.2008.06.034

32 M. P. Morales, S. Veintemillas-Verdaguer, M. I. Montero, C. J. Serna, A. Roig, L. Casas, B. Martinez, and F. Sandiumenge: Chem. Mater. 11 (1999) 3058. https://doi.org/10.1021/cm991018f 